\title{
Pendidikan Masyarakat Desa Keban Tahun 1990-2014
}

\section{UNDERDEVELOPMENT COMMUNITY EDUCATION KEBAN VILLAGE YEAR 1990-2014}

\author{
Fitri Yanti ${ }^{1)}$, M Hafiz ${ }^{2)}$ \\ Program Studi Pendidikan Sejarah, Fakultas Keguruan dan Ilmu Pendidikan, \\ Universitas Riau Kepulauan, Batam, Kepulauan Riau, Indonesia \\ ${ }^{1)}$ Fit.ugm@gmail.com ${ }^{2)}$ mhafis@gmail.com
}

\begin{abstract}
Abstrak
Tujuan penelitian ini adalah untuk menjelaskan keterbelakangan pendidikan di Desa Keban Karimun tahun 1990-2014. Jenis penelitian ini kualitatif, dengan menggunakan metode historis. Metode ini dilakukan dengan 4 tahapan yaitu: 1) Heuristik yaitu pengumpulan data;2) Kritik sumber yaitu berupa validasi data; 3) Interpretasi yaitu penafsiran dan penggambaran; dan 4) Historiografi yaitu penulisan sejarah. Hasil penelitian ini menjelaskan bahwa keterbelakangan pendidikan di Desa Keban dilihat dari segi sosial adalah hasil pola fikir masyarakat yang menganggap pendidikan tidak penting, hal ini menyebar dari satu keluarga ke keluarga yang lain, karena secara sosial ikatan keluarganya sangat kuat, kedua dari segi ekonomi masyaraat kebanyakan bekerja sebagai nelayan sehingga tidak dapat memenuhi kebutuhan pendidikan dan ketiga budaya masyarakat lebih cenderung mempelajari ilmu keagamaan seperti pengenalan huruf $\mathrm{Al}-$ Quran.
\end{abstract}

Kata kunci: Keterbelakangan, Pendidikan, Masyarakat,

\begin{abstract}
The purpose of this study is to explain the history of retardation in the village of Keban Karimun years 1990-2014. This type of research is qualitative, using the historical method. This method involves four stages: 1) Heuristics of data collection; 2) Criticism source in the form of data validation; 3) Interpretation is interpretation and depiction; and 4) Historiography, namely the writing of history. The results of this study explains that the backwardness of education in the village of Keban in terms of social is the result of thought patterns of people who think education is not important, it is spread from one family to another, because it is socially family ties are very strong, both in terms of the local economy most worked as a fisherman that can not meet the needs of education and culture a third more likely to learn religious knowledge such as the introduction of the letter of the Koran.
\end{abstract}

Keywords: Underdevelopment, Education, Community,

\section{PENDAHULUAN}

Desa Keban Karimun berdiri sekitar tahun 1961. Desa Keban memiliki 18 RT dan 9 RW, yang terdiri dari 9 kampung diantaranya Kampung Keban, Kampung Bahan, Kampung Buah Rawa, Kampung Kang, Kampung Pasai, Selat Binga, Sungai Sapari, 
Kampung Tanjung Semukul dan Kampung Tanjung Judah dengan populasi keseluruhan penduduknya sekitar 2698 jiwa. Dilihat dari segi ekonomi masyarakat Desa Keban sebagian besar bekerja sebagai nelayan. Masyarakat masih sangat menggantungkan hidup terhadap laut. Keadaan sosial masyarakat masih bersifat kekerabatan, artinya beberapa desa masyarakatnya masih memiliki ikatan tali persaudaraan dari satu kampung dengan kampung yang lain. Interaksi masyarakat masih terjalin dengan sangat solid dan sifat gotong royong yang tinggi, dilihat dari kebudayaan masyarakat setempat memiliki rasa kepedulian satu dengan yang lainnya yang sangat tinggi seperti terdapat pada setiap acara aqikahan dan termasuk acara keagamaan lainnya. Mayoritas masyarakat desa Keban bersuku Melayu dan beragama Islam.

Namun tingginya rasa kekeluargaan, tidak sebanding dengan pendidikan yang dijalani atau ditempuh oleh penduduk Keban, dan dikalangan masyarakat banyak yang menikah di usia muda dan mereka banyak yang beranggapan sudah bisa mencari uang sudah cukup sehingga tidak perlu bersekolah, akibatnya keterbelakangan di sektor pendidikan. Faktanya apabila dilihat dari rata-rata pendidikan terakhir masyarakat yang memiliki ijazah lulusan Strata Satu (S1) masih sangatlah sedikit, dan kebanyakan dari mereka masih banyak yang hanya berpendidikan sampai dijenjang Sekolah Dasar (SD) dan bahkan masih ada juga yang tidak dapat membaca sama sekali. Untuk dapat melihat kualitas penduduk di suatu daerah dapat dilihat dari berbagai indikator, salah satunya pendidikan. Pendidikan merupakan bekal bagi umat manusia dalam menempuh perjalanan hidup yang tentunya berdinamika. Lalu apa sebenarnya yang menyebabkan keterbelakangan pendidikan di Desa Keban.

\section{Sub-Topic}

\section{Konsep pendidikan}

Ki Hajar Dewantara (dalam Zen, 2012: 43) mengartikan pendidikan pada umumnya berarti daya-upaya untuk memajukan bertumbuhnnya budi pekerti (kekuatan batin, karakter), pikiran (intelek dan tubuh anak) dalam Taman Siswa tidak boleh dipisahpisahkan bagian-bagian itu supaya memajukan kesempurnaan hidup, kehidupan, dan penghidupan anak-anak yang dididik, selaras dengan dunianya. Pada hakikatnya pendidikan disimpulkan sebagai suatu kegiatan yang secara sadar dan disengaja, serta penuh tanggung jawab yang dilakukan oleh orang dewasa kepada anak sehingga timbul 
interaksi dari keduanya agar anak tersebut mencapai kedewasaan yang dicita-citakan dan berlangsung terus menerus.

\section{Pentingnya Pendidikan}

Menurut Ahmadi (2003: 75) pentingnya pendidikan dapat dilihat dari berbagai segi yaitu pertama, segi anak-anak adalah mahkluk yang sedang tumbuh, oleh karena itu pandidikan penting sekali karena mulai sejak bayi belum dapat berbuat sesuatu untuk kepentingan dirinya, baik untuk mempertahankan hidup maupun merawat diri, semua kebutuhan tergantung ibu/orang tua. Kedua, segi orang tua, pentingnya pendidikan adalah karena dorongan orang tua yaitu hati nuraninya yang terdalam yang mempunyai sifat kodrati untuk mendidik anaknya baik dalam segi phisik sosial, emosi maupun inteligensinya agar memperoleh keselamatan, kepandaian, agar mendapat kebahagiaan hidup yang mereka idam-idamkan sehingga ada tanggung jawab moral atas hadirnya anak tersebut yang diberikan oleh Tuhan Yang Maha Kuasa untuk dapat dipelihara dan dididik dengan sebaik-baiknya.

Selanjutnya pentingnya pendidikan menurut fungsi dan kegunaan (Ahmadi, 2003: 77) sebagai berikut:

1. Untuk pengembangan individu, seperti kita ketahui manusia sebagai makhluk berbudaya dapat mengembangkan dirinya sedemikian rupa sehingga mampu membentuk norma dan tatanan kehidupan yang didasari oleh nilai-nilai luhur untuk kesejahteraan hidup, baik perorangan maupun untuk kehidupan bersama.

2. Bagi pendidik pada umumnya dengan memahami pendidikan pendidik dapat

3. Memudahkan praktek pendidikan, dengan bekal ilmu pendidikan kegiatan pendidikan dapat direncanakan secara teratur dan sistematis menuju tujuan yang telah ditetapkan.

4. Dapat menimbulkan rasa kecintaan pada diri pendidik terhadap tugasnya, terhadap anak didik dan terhadap kebenaran. Dengan demikian pendidikan akan selalu berusaha mempelajari dirinya.

5. Dapat menghindari banyak kesukaran dan kesalahan dalam melaksanakan praktek pendidikan. 
6. Segi pembangunan, seperti diketahui dalam GBHN tentang dasar dan tujuan pendidikan nasional : "Pendidikan Nasional berdasarkan atas Pancasila dan bertujuan untuk meningkatkan ketakwaan terhadap Tuhan Yang Maha Esa, kecerdasan, keterampilan mempertinggi budi pekerti, memperkuat kepribadian dan mempertebal semangat kebangsaan agar dapat menumbuhkan manusiamanusia pembangunan yang dapat membangun dirinya sendiri serta, bersamasama bertanggung jawab atas pembangunan bangsa”.

Begitu pentingnya pendidikan untuk pembangunan bangsa maka pemerintah telah berusaha keras untuk (a) meningkatkan usaha pemerataan pendidikan; (b) meningkatkan mutu pendidikan dalam setiap tingkat pendidikan; (c) meningkatkan relevansi pendidikan terhadap kebutuhan masyarakat dan kebutuhan akan melaksanakan pembangunan yang sekarang sedang akan terus dilaksanakan bahkan semakin ditingkatkan; (d) Meningkatkan efektifitas dan efisiensi pelaksanaan kegiatan pendidikan di semua jenjang pendidikan.

\section{Pendidikan dan Masyarakat}

Pendidikan sekolah telah menyebar dan meluas ke berbagai pelosok tanah air sehingga pendidikan sekolah memiliki peran yang penting dalam meningkatkan perubahan sosial ekonomi masyarakat. Masyrakat menyadari bahwa sekolah tidak hanya sebagai sarana untuk mendapatkan pekerjaan pada setiap lulusannya, tetapi sekolah merupakan sarana untuk mencerdaskan kehidupan bangsa. Pendidikan sekolah membekali anak didiknya dengan pengetahuan yang berguna agar setiap lulusannya dapat hidup mandiri terutama pada pendidikan yang bersifat kejuruan. Adapun pendidikan umum mengharapkan siswanya dapat melanjutkan pendidikannya ke jenjang yang lebih tinggi di samping membekali dengan kemampuan atau keterampilan dasar. Komunitas masyarakat mendidik generasi mudanya melalui orang yang dipercaya untuk menangani hal tersebut terutama yang berhubungan pewarisan nilai budaya yang disampaikan secara lisan, begitu juga keterampilan dan kepercayaan yang dianut sebagai milik masyarakat. Dengan demikian, tanggung jawab masyarakat berkembang sesuai dengan pelestarian nilai budaya yang dimiliki pada generasi mudanya (Waluya, 2007: 16).

\section{Konsep Masyarakat}


Menurut Berger (dalam Murdiatmoko. 2007 : 18), defenisi masyarakat adalah suatu keseluruhan kompleks hubungan manusia yang luas sifatnya. Pengertian keseluruhan kompleks dalam defenisi tersebut berarti bahwa keseluruhan itu terdiri atas bagian-bagian yang membentuk suatu kesatuan, misalnya dalam tubuh manusia terdapat bagian-bagian yang membentuk suatu sistem organik biologis, seperti jantung, hati, otak, dan paru-paru. Kesatuan dari bagian-bagian tersebut yang membentuk sistem yang namanya manusia. Demikian pula dengan masyarakat, di dalamnnya terdiri atas begianbagian yang membentuk hubungan sosial, misalnya hubungan orangtua dan anak, hubungan guru dan murid, hubungan atasan dan bawahan, yang keseluruhan hubungan yang luas itu di sebut masyarakat. Dengan demikian, pendidikan merupakan usaha untuk mencetak, memperoleh, dan mengembangkan sumber daya manusia yang dibutuhkan dalam pembangunan Negara.

Setiap masyarakat mempunyai komponen-komponen dasarnya, sehingga dapat dikatakan bahwa masyarakat senantiasa merupakan sistem karena mencakup berbagai komponen dasar yang sangat berkaitan secara fungsional yaitu (Soekanto, 2010: 24).:

1) Populasi, yakni warga-warga suatu masyarakat yang dilihat dari sudut pandang kolektif. Secara sosiologis, aspek-aspek sosiologis yang perlu dipertimbangkan misalnya aspek-aspek genetik yang konstan, variabel-variabel genetik, dan variablevariabel demografi.

2) Kebudayaan, yakni hasil karya, ciptaan, dan rasa dari kehidupan bersama yang mencakup, sistem lembaga-lembaga dan informasi.

3) Hasil kebudayaan materil.

4) Oraganisasi sosial, yakni jaringan antara warga-warga masyarakat yang bersangkutan, antara lain mencakup, warga masyarakat secara individual, perananperanan, kelompok-kelompok sosial, kelas-kelas sosial.

5) Lembaga-lembaga sosial dan sistemnya.

\section{Struktur sosial dalam masyarakat Melayu}

Membahas tentang struktur sosial dalam masyarakat Melayu, tidak lepas dari adat istiadat dan kebudayaan. Menurut Isjoni (2007: 30) adat adalah satu konsep yang 


\section{Yanti: Pendidikan Masyarakat Desa Keban Tahun 1990-2014}

menjelaskan keseluruhan cara hidup Melayu di alam Melayu. Masyarakat Melayu mengatur kehidupan mereka dengan adat agar setiap anggota adat hidup beradat, seperti adat alam, hukum adat, adat raja, adat negeri, adat kampung, adat memerintah, adat suami istri, adat berbicara dan sebagainya. Adat adalah fenomena keserumpunan yang mendasari kebudayaan Melayu.

Menurut sudut pandang lain adat juga merupakan struktur yang menghubung seluruh kehidupan manusia Melayu, yang menegaskan sifat, diri, kepribadian, identitas atau jati diri manusia masyarakat budaya Melayu. Adat adalah jati diri yang menyatupadukan, menyimpul dan mengikat seluruh anggota masyarakat. Oleh karena itu kedudukan seorang Melayu bukan ditentukan oleh keturunan (bangsa), kekayaan, kealiman, gaya hidup, ketinggian ilmu pengetahuan, tetapi ditentukan oleh pelaksanaan orang yang "beradat", "tahu adat", dan “cukup ajar". Satu kehalusan perlakuan, sikap, tindakan, tutur kata, bermoral, beretika, berakhlak mulia, seperti yang telah ditetapkan oleh adat Melayu.

Adat sebagai usaha memanusiakan Melayu terpancar di dalam definisi Melayu yang tercatat di dalam naskah "Adat Raja-Raja Melayu” menurut Tardjan Hadidjada, 1952 (dalam Isjoni. 2007: 31). adat raja-raja Melayu antara lain;

1) Merendah, yaitu merendahkan diri, tidak mau membesarkan diri, baik dari segi adabtertib, bahasa penuturan, perjalanan dan kedudukan.

2) Tidak kasar, yaitu berlemah lembut tidak berlebih-lebihan, tidak berkurangan.

3) Bersahaja, yaitu pertengahan (sederhana) dalam perlakuan, perbuatan, perkataan, pakaian, makanan dan perjalanannya.

4) Adab pandai menjaga diri, yaitu padai mengawal kata-kata, penglihatan dan pandangan dari perkara yang keji.

Apa yang dikemukakan di atas ialah elemen keunggulan diri dan perwatakan Melayu. Perwatakan Melayu yang budiman adalah citra, pembawaan, gaya Melayu yang sudah lekat dengan kemelayuan. Budi pekerti, budi bahasa, etika Melayu yang berberkonsep ketuhanan. Adat dan budi sebagai elemen unggul Melayu ini yang mampu meletakkan kembali derajat, harkat dan martabat, manusia Melayu di tempat tertinggi, dunia dan akhirat. Ciri keunggulan inilah yang menjadikan Melayu itu Melayu.

Orang Melayu dilihat dari berbagai aspek kehidupan saat ini relatif tertinggal dibandingkan dengan suku lain di Asia Tenggara. Ketertinggalan tersebut diperkirakan 
dalam dasawarsa mendatang akan semakin meluas. Hal ini disebabkan sumber daya yang memungkinkan untuk merebut dan memanfaatkan peluang yang terbuka pada masa mendatang berada di luar kendali orang Melayu. Kondisi tersebut bersumber baik dari sikap mental dan tingkat achievement (mikro) maupun kendala struktural yang berakar dari sejarah masa lampau. Cendikiawan dan pemimpin Melayu menyadari kondisi-kondisi tersebut di atas dan telah mengemukakan berbagai alternatif pemecahannya. Akan tetapi, solusi yang diajukan selalu bersifat apologia sehingga tidak pernah tuntas dan menjawab inti permasalahannya (Isjoni, 2007: 30).

\section{METODOLOGI}

Jenis penelitian ini kualitatif dengan metode historis. Metode historis terdiri dari Heuristik, kritik sumber, interpretasi, dan historiografi. Dalam penelitian ini peneliti mengumpulkan data dari tokoh masyarakat, alim ulama, lurah dan warga desa Keban. Data yg di dapat dari informna akan dilakukan kritik sumber secara internal dan eksternal, dengan menguji kebenaran informasi yg didapat dari informan sekaligus alat pengendalian atau pengecekan proses-proses serta untuk mendeteksi adanya kekeliruan yang mungkin terjadi. Kemudian menafsirkan atau memberi makna kepada fakta-fakta atau bukti-bukti yang didapat dan terakhir historiografi, penulisan peristiwa sejarah, dan juga merupakan tahap terakhir dalam penyusunan sejarah. Dalam penelitian ini akan disajikan dalam bentuk historiografi yang tersusun secara sistematis dan kronologis mengenai faktor-faktor penyebab keterbelakangan pendidikan masyarakat di Desa Keban dari tahun 1990-2014

\section{PEMBAHASAN}

\section{Perubahan dan Perkembangan Pendidikan dari Tahun 1990an Dan 2000an}

Tahun 1990an masyarakat Desa Keban di bidang pendidikan belum berkembang karena keterbatasan sarana prasarana terutama sarana pendidikan. Desa Keban hanya memiliki sekolah dasar dengan bangunan masih berdinding papan dan fasilitas seadanya. Sedangkan untuk tingkat Sekolah Menengah Pertama (SMP) dan Sekolah Menengah Atas 
(SMA) harus ke kecamatan (Moro) dan ke kabupaten (Karimun). Ini menyebabkan pendidikan masyarakat di Desa Keban pada sekitar 1990an belum berkembang. Selain itu juga di karenakan kebiasaan masyarakat pada saat itu malas bersekolah. Bagi mereka bersekolah itu tidak perlu asalkan sudah bisa mencari uang saja sudah lebih dari cukup.

Bagi masyarakat sudah tamat Sekolah Dasar (SD) saja sudah sangat bersyukur. Kebiasaan orang tua pada masa itu apabila anak perempuannya sudah remaja maka akan disuruh untuk menikah, sedangkan anak laki-laki disuruh bekerja mencari ikan di laut. Sehingga menjadi sangat sulit bagi masyarakat Desa Keban untuk maju dan berkembang pendidikannya.Pada tahun 2000an juga belum juga ada perubahan yang signifikan, tidak berbeda jauh dengan tahun 1990an. Sehingga sampai tahun 2003 berdirinya Sekolah Menengah pertama (SMP), dan juga tahun 2011 berdiri Sekolah Menengah Atas di Desa Keban, dan baru lah mulai perlahan ada nampak perubahan mulai ada yang menempuh pendidikan hingga SMP dan SMA, namun tidak sepenuhnya dimanfaatkan oleh

masyarakat Desa Keban secara maksimal, disebabkan oleh masih belum sadarnya masyarakat Desa Keban akan pentingnya pendidikan dan juga masalah ekonomi yang tidak menentu, membuat sulit masyarakat untuk menempuh pendidikan. Sehingga hasilnya masih jauh dari harapan.

Beberapa aspek yang menyebabkan keterbelakangana pendidikan di Desa Kebann tahun1990-2014.

\section{Peranan Aspek Sosial}

Kehidupan Sosial masyarakat yang terdapat di Desa Keban pada masa 1990an merupakan masyarakat yang memiliki ikatan kekeluargaan antara satu keluarga dengan keluarga lainya, atau lebih dikenal dengan hubungan persaudaraan. Dengan demikian kondisi kehidupan sosial masyarakat desa Keban merupakan masyarakat yang berkelompok memiliki hubungan persaudaraan yang kuat.

Menurut Peter L. Berger (dalam Murdiatmoko. 2007 : 18), masyarakat adalah suatu keseluruhan kompleks hubungan manusia yang luas sifatnya. Pengertian keseluruhan kompleks dalam defenisi tersebut berarti bahwa keseluruhan itu terdiri atas bagian-bagian yang membentuk suatu kesatuan. Demikian pula dengan kehidupan masyarkat di Desa Keban yang membentuk hubungan sosial, misalnya hubungan orangtua dan anak, hubungan tetangga dengan masyarakat lainnya. 
Masyarakat di Desa Keban sangat menjaga kekompakan, misalnya apabila salah satu warga ada acara hajatan, masyarakat saling membantu dalam menyiapkan acara. Warga bergotong royong, ramai-ramai ke hutan untuk mencari kayu, untuk membuat tenda, serta panggung hajatan. Sedangkan tuan rumah memasakkan makanan buat dimakan bersama-sama oleh warga. Demikianlah kekompakkan warga di sana terjalin, warganya tidak sungkan-sungkan membantu warga lain yang membutuhkan pertolongan. Seperti pepatah "berat sama dipikul, ringan sama di jinjing.

Namun dibalik keakaraban masyarakat Desa Keban ada suatu kebiasaan masyarakat yang mempengaruhi pemikiran dikalangan mereka yaitu kurangnya memiliki pemikiran jauh kedepan. Masy arakatmasih menganggap pendidikan tidak penting, tidak menghasilkan, melainkan menyusahkan kehidupan, bahkan ada orang tua yang marah apabila anaknya rajin dan tekun dengan sekolahnya. Mereka takut anaknya tidak bisa membantu pekerjaan mereka. Bagi masyarakat terutama dikalangan orang tua, anak tidak butuh sekolah tinggi-tinggi, hanya cukup bisa membaca dan berhitung.

Meskipun sebelum tahun 1990-an Sekolah Dasar sudah berdiri, dengan bentuk dan bangunan sekolah masih berdinding papan dengan fasilitas seadanya, namun, masih banyak juga masyarakatnya yang tidak ingin untuk bersekolah, dikarenakan mereka berpikir kalau berkerja lebih utama dibanding bersekolah.

Kebiasaan lain masyarakat Desa Keban pada masa 1990an yaitu mereka kurang terbiasa merantau. Mereka tidak mau meninggalkan kampung apalagi melepas anaknya keluar kampung untuk sekolah. Bagi mereka adalah sesuatu hal yang sangat berat. Mereka tetap dengan hidup berprinsip biar tak makan yang penting ngumpul. Artinya biarlah hidup susah asal tetap bersama.

\section{Aspek Kehidupan Ekonomi}

Mata pencaharian masyarakat sangat mempengaruhi kondisi ekonomi serta kelangsungan hidup keluarga. Mata pencaharian penduduk di Desa Keban sangat beragam. Dapat dilihat pada table berikut:

\section{Tabel 1. Mata Pencaharian Penduduk di Desa Keban Karimun Tahun 2014.}




\begin{tabular}{|c|c|c|c|}
\hline No. & Mata Pencaharian & Jumlah (Jiwa) & Persentase (\%) \\
\hline 1 & Nelayan & 1404 & 52,21 \\
\hline 2 & Petani & 47 & 1,75 \\
\hline 3 & Pedagang & 12 & 0,46 \\
\hline 4 & PNS & 26 & 0,96 \\
\hline 5 & Lain-Lain & 1200 & 44,62 \\
\hline & Jumlah & 2689 & 100 \\
\hline
\end{tabular}

Sumber: Inventaris Desa Keban

Berdasarkan tabel di atas mayoritas penduduk Desa Keban bermata pencaharian sebagai nelayan, dan kemudian disusul pekerjaan lain-lain, petani, wiraswasta dan paling sedikit PNS (Pegawai Negeri Sipil) .

\section{a. Sektor Ekonomi Kelautan}

Penduduk Desa Keban adalah penduduk asli melayu yang bertempat tinggal di persisir pantai dalam perekonomian masyarakat bahkan merupakan sarana untuk mencari dengan cara melaut. Diperkirakan pada tahun 1990-1997 masyarakat rata-rata menangkap ikan masih menggunakan dengan alat yang terbilang sederhana dengan perahu dayung dan layar kecil belum banyak perahu mesin, sehingga hasil penghasilannya sedikit. Terkadang hasil tangkapannya sedikit maka penghasilannya pun sedikit. Apalagi bila terjadi cuaca buruk, ombak besar, masyarakat terpaksa mengurungkan niatnya untuk berangkat kelaut.

Dengan demikian kondisi ekonomi kelautan di Desa keban pada tahun 1998-2011 masih belum berkembang. Meskipun ada sedikit kemajuan, namun masih belum memberikan pengaruh terhadap keadaan kelautaan di Desa Keban Karimun, terutama penghasilan para nelayan, dan secara tidak langsung juga berdampak terhadap kelangsungan pendidikan para anak nelayan. Pada tahun 2012-2014 barulah pemerintah kebupaten mulai memperhatikan nasib nelayan, dengan memberikan bantuan sebuah perahu mesin kepada masing-masing kepala keluarga. Sehingga memudahkan bagi nelayan dalam mencari ikan, dan menambah penghasilan masyarakat di sektor ekonomi kelautan. 


\section{b. Sektor Pertanian.}

Sektor pertanian di Desa Keban belum berkembang secara maksimal karena Desa Keban luas daratan yang hanya $21.73 \%$ dari seluruh luas wilayah. Masyarakat Desa Keban cenderung memilih kehidupan dengan menelayan dari pada sebagai petani. Akan tetapi pertanian Desa Keban diharapkan dapat lebih dikembangkan mengingat masaih ada lahan yang belum diolah yang dikemukakan untuk dibudidayakan sebagai lahan tanaman pangan terutama untuk kebutuhan masyarakat lokal. Meskipun ada beberapa Satuan Pemukiman Transmigrasi yang terdapat di Dusun Keban yang berasal dari daerah jawa, namun belum mampu mencukupi kebutuhan pangan masyarakat.

\section{c. Kondisi Ekonomi Sektor Perkebunan}

Sektor Perkebunan di Desa Keban belum tergarap secara maksimal, perkebunan yang berkembang adalah hanya perkebunan rakyat. Sejak tahun 1990 dari hasil perkebunan rakyat unggulan di sektor perkebunan adalah karet, kelapa dan jengkol, dimana lokasinya menyebar diseluruh wilayah Desa Keban. Dari hasil panen jengkol didapat sekali dalam 1 Tahun karna hanya merupakan tanaman tahunan, pohon- pohon Karet yang ada di Desa Keban merupakan pohon Karet alami dari pembenihan biji yang hasil getahnya kurang maksimal dibandingkan dengan pohon karet okulasi, dan sistem okulasi pun mulai digarap pada tahun 2013.

Dengan demikian terlihat bahwa kondisi ekonomi di sektor perkebunan juga belum menghasilkan perkembangan yang baik, masih jauh dari harapan. Tidak jauh berbeda dengan sektor ekonomi kelautan dan pertanian. Harus ada usaha serius apabila ingin meningkatkan ekonomi, yaitu dengan kerjasama dari berbagai elemen, baik itu antar masyarakat dan pemerintah. Supaya terwujudnya kesejahteraan masyarakat terutama dibidang pendidikan.

\section{Aspek budaya}

Etnis atau suku yang terdapat di Desa Keban adalah Melayu, Bugis, jawa, Batak, dan China. Jumlah penduduk berdasarkan agama di Desa Keban sebagai berikut: 
Tabel 2. Jumlah Penduduk Berdasarkan Etnis di Desa Keban Karimun Tahun 2014.

\begin{tabular}{|c|l|c|c|}
\hline No. & \multicolumn{1}{|c|}{ Etnis } & Jumlah (Jiwa) & Persentase (\%) \\
\hline 1. & Melayu & 2400 & 89,26 \\
2. & Bugis & 101 & 3,76 \\
3. & Jawa & 100 & 3,71 \\
4. & China & 50 & 1,86 \\
5. & Batak & 38 & 1,41 \\
\hline \multicolumn{2}{|c|}{ Jumlah } & 2689 & 100 \\
\hline
\end{tabular}

Sumber : Kantor Desa Keban

Penduduk di Desa Keban terdiri dari beragam suku. Mayoritas beretniskan Melayu sebanyak 89,26\%. Sedangkan Bugis dan Jawa masing-masiing 3,76\% dan 3,71\%, Cina 1,86\%, Batak 1,41\%. Masyarakat Desa Keban ke seluruhannya merupakan masyarakat Melayu.

Faktor kedekatan wilayah antara Malaysia dan Singapura membuat dialek bahasa yang di gunakan oleh masyarakat Melayu desa Keban hampir sama dengan bahasa Melayu yang di gunakan seperti penggunaan bahasa Melayu yang terdapat di Malaysia dan Singapura. Akhiran dari setiap kata kebanyakan mengukan huruf “E”, misalkan pengunaan kata saya menjadi saye, dimana menjadi dimane, siapa menjadi siape dan lebih banyak lagi. Dialek bahasa Melayu tersebut merupakan bahasa keseharian digunakan oleh masyarakat setempat di Desa Keban. Suku Melayu desa Keban merupakan suku Melayu yang mendiami wilayah pesisir bagian Timur Kabupaten Karimun, berbatasan dengan Kota Batam.

Budaya Melayu yang sangat identic dengan Islam snagat melekat pada masyarakat. Masyarakat lebih cendrung belajar pengenalan huruf Al-Qur'an dan pembelajaran yang berkaitan dengan pembelajaran ilmu agama Islam. Sedangkan pendidikan umum tidak terlalu di pentingkan. Sehingga banyak di kalangan masyarakat yang mengalami buta akan pengenalan huruf, tidak bisa membaca dan menulis.

Masyarakat lebih cenderung kepada tradisi kebudayaan yang bersifat adat istiadat peninggalan nenek moyang dan masih di terapkan hingga sekarang ini. Tradisi adat istiadat tersebut dapat dilihat pada saat anak umur 5 tahun disuruh orang tuanya belajar ilmu Al-Quran dan ilmu agama. Biarpun anaknya sudah belajar di Sekolah Dasar (SD) setelah pulang, dan makan siang tetap diwajibkan oleh orang tuanya pergi kerumah Pak Imam untuk belajar ilmu Al-Quran dan ilmu agama. 
Dari situlah dapat dilihat pengaruh budaya terhadap pendidikan hanya kuat di bidang pendidikan agama dan ilmu Al-Quran, sedangkan di bidang pendidikan umum tidak memberikan dampak perkembangan yang berarti. Sehingga sangat sedikit masyarakat yang menjadi PNS serta bekerja pemerintahan dan instansi-instansi lainnya. Masyarakat masih memiliki kecendrungan untuk bekeja sebagai nelayan yang sudah menjadi tradisi nenek moyang mereka yang sudah turun temurun.

Dari kajian di atas dapat penulis simpulkan dari sejarah keterbelakangan pendidikan di Desa Keban dipengaruhi oleh pola fikir masyarakat Desa Keban masa itu masih menyepelekan pendidikan, menganggap pendidikan tidak terlalu penting. Selain itu aspek ekonomi juga menjadi faktor penyebab keterbelakangan pendidikan, dan ditambah lagi dengan kondisi fasilitas pendidikan yang masih belum lengkap di awal tahun 1990. Sedangkan aspek budaya dengan kecendrungan lebih kepada pedidikan agama, dan tidak terlalu mementingkan Pendidikan umum.

\section{KESIMPULAN DAN SARAN}

\section{Kesimpulan}

Berdasarkan hasil penelitian di atas, dapat disimpulkan hal-hal sebagai berikut :

1. Latar belakang keterbelakangan pendidikan masyarakat Desa Keban Karimun tahun 1990-2014 disebabkan beberapa aspek yaitu dari segi sosial terdapatnya pola fikir masyarakat yang menganggap pendidikan tidak terlalu penting. Segi ekonomi masyarakat kebanyakan bekerja sebagai nelayan dengan penghasilan yang tidak pasti, sehingga tidak dapat memenuhi kebutuhan pendidikan. Segi Budaya masyarakat lebih cendrung mempelajari ilmu keagamaan seperti pengenalan huruf Al Quran, sedangkan di bidang pendidikan umum tidak memberikan dampak perkembangan yang berarti

2. Selain itu kondisi fasilitas pendidikan yang masih belum lengkap di awal tahun 1990 juga memperngaruhi keterbelakangan pendidikan masyarakat Desa Keban Karimun. 


\section{Saran}

Melihat Berbagai penomena diatas, maka penulis maka disarankan hal-hal sebagai berikut :

1. Pemerintahan berseta jajarannya lebih memperhatikan kehidupan masyarakat dalam mengembangkan usaha pendidikan di Desa Keban.

2. Melakukan penyuluhan kepada masyarakat akan pentingnya pendidikan dan memenuhi sarana perasarana pendidikan di Desa Keban

3. Memberikan kemudahan bagi masyarakat desa untuk memberikan baeasiswa dan mengurangi angka penganggurandengan membuka lapangan kerja dan lebih menggali potensi lokal.

\section{DAFTAR PUSTAKA}

Ahmadi, Abu. 2003. Ilmu Pendidikan. Jakarta: Rineka Cipta.

Ali, Mohammad. 2009. Pendidikan untuk pembangunan nasional, Jakarta: Grasindo.

Daliman, A. 2012. Metode Penelitian Sejarah. Yogyakarta : Ombak

Idrus, Muhammad. 2009: 23. Metode Penelitian Ilmu Sosial. Jakarta: Erlangga

Isjoni. 2007. Orang Melayu di Zaman yang Berubah, Yogyakarta: Pustaka Belajar.

Murdiatmoko, Janu. 2007. Sosiologi Memahami dan Mengkaji Masyarakat. Bandung: Grafindo Media Pratama.

Rohman, Arif. 2013. Memahami Ilmu Pendidikan, Yogyakarta: Aswaja Pressindo.

Samadi. 2007, Geografi, Bogor: Yudhistira Quadra

Soekanto, Soerjono. 2007. Sosiologi Suatu Pengantar. Jakarta: P.T.Raja Grafindo.

Syafaruddin. 2012. Pendidikan dan Pemberdayaan Masyarakat, Medan: Perdana Publishing.

Waluya, Bagja. 2007. Sosiologi Menyelami Fenomena Sosial di Masyarakat, Bandung: pt Setia Purna Inves.

Zein, Syafril Zelhendri, dkk. 2012. Pendidikan dan pemberdayaan Masyarakat, Padang: Sukabina Pres 